\title{
Tropicibacter multivorans sp. nov., an aerobic alphaproteobacterium isolated from surface seawater
}

\author{
Correspondence \\ David R. Arahal \\ arahal@uv.es
}

\author{
Teresa Lucena, María J. Pujalte, María A. Ruvira, Esperanza Garay, \\ M. Carmen Macián and David R. Arahal
}

\author{
Departamento de Microbiología y Ecología, Colección Española de Cultivos Tipo (CECT), \\ Universidad de Valencia, Valencia, Spain
}

The family Rhodobacteraceae in the class Alphaproteobacteria of the phylum Proteobacteria mainly comprises bacteria of aquatic origin, many of them requiring $\mathrm{NaCl}$ for growth. Within this family, the so-called Roseobacter group is one of the most abundant and ubiquitous. Almost two decades since the description of Roseobacter (Shiba, 1991), this group has expanded to more than 50 genera, as can be seen in the last release (LTPs102_SSU) of the Living Tree Project database (Yarza et al., 2010).

The genus Tropicibacter belongs to the family Rhodobacteraceae and currently comprises only one species, Tropicibacter naphthalenivorans, described on the basis of a single isolate from seawater collected at Semarang Port in Indonesia (Harwati et al., 2009). This marine bacterium was capable of degrading hydrocarbons, specifically naphthalene, as its name indicates.

The GenBank/EMBL/DDBJ accession number for the 16S rRNA gene sequence of strain $\mathrm{MD}^{\top}{ }^{\top}$ is FR727679.

Five supplementary figures and a supplementary table are available with the online version of this paper.
A recently isolated strain, $M D 5^{\mathrm{T}}$, obtained from coastal seawater of the western Mediterranean Sea, has been characterized as a novel member of the genus Tropicibacter that shows the highest 16S rRNA gene sequence similarity to T. naphthalenivorans.

Strain $\mathrm{MD}^{\mathrm{T}}$ was isolated from surface seawater collected at Malvarrosa Beach $\left(39^{\circ} 28^{\prime} 29^{\prime \prime} \mathrm{N} 0^{\circ} 19^{\prime} 23^{\prime \prime} \mathrm{W}\right.$; temperature $25^{\circ} \mathrm{C}$; pH 8) in Valencia, Spain, in July 2008. Seawater was plated on 1/100-strength marine agar (MA) plates [0.04\% marine broth $(\mathrm{MB}), 1.2 \%$ bacteriological agar and aged, filtered seawater to maintain the salts concentration]. Incubation was done at $26{ }^{\circ} \mathrm{C}$ over the course of several days, with periodic examination and isolation of new colonies. Isolated colonies were streaked on the same medium and subcultured under the same conditions until pure cultures were obtained. Strain $\mathrm{MD}^{\mathrm{T}}$ was isolated after 4 days of incubation and was maintained as cell suspensions in MB plus $20 \%$ glycerol at $-80{ }^{\circ} \mathrm{C}$. Strain $\mathrm{MD}^{\mathrm{T}}$ was grown routinely on MA and in $\mathrm{MB}$ at $28{ }^{\circ} \mathrm{C}$ for $24-48 \mathrm{~h}$ to prepare inocula. Media other than MA and MB were supplemented with half-strength artificial seawater (ASW; 
$400 \mathrm{mM} \mathrm{NaCl}, 100 \mathrm{mM} \mathrm{MgSO} 4 \cdot 7 \mathrm{H}_{2} \mathrm{O}, 20 \mathrm{mM} \mathrm{KCl}$ and $20 \mathrm{mM} \mathrm{CaCl} 2.2 \mathrm{H}_{2} \mathrm{O}$ ) or marine cations supplement (MCS; Farmer \& Hickman-Brenner, 2006). Suspension media for microscopic observations or miniaturized testing were also prepared using salt-supplemented solutions. The phenotypic characteristics of the strain were determined following methods described previously (Macián et al., 2001) for microscopic observation of cells, colony characteristics on $\mathrm{MA}$, oxidase, catalase, nitrate reduction, fermentation of Dglucose in $\mathrm{O} / \mathrm{F}$ medium, temperature range for growth $(4,15$, $28,37,40$ and $45^{\circ} \mathrm{C}$ ), hydrolysis of gelatin, casein, starch, lecithin, alginate, Tween 80 and DNA and use as sole carbon sources of 26 carbohydrates, 12 organic acids and 16 amino acids and amines on basal medium agar [BMA; $50 \mathrm{mM}$ Tris/ $\mathrm{HCl}, \mathrm{pH} 7.5 ; 19 \mathrm{mM} \mathrm{NH} \mathrm{NH}_{4} \mathrm{Cl} 0.33 \mathrm{mM} \mathrm{K} \mathrm{HPO}_{4} .3 \mathrm{H}_{2} \mathrm{O}$; $0.1 \mathrm{mM} \mathrm{FeSO}_{4} .7 \mathrm{H}_{2} \mathrm{O}$ and $1.3 \%(\mathrm{w} / \mathrm{v})$ purified agar (Oxoid) on half-strength ASW; Baumann \& Baumann, 1981].

API ZYM, API 20NE (bioMérieux) and GN2 (Biolog) tests were performed in duplicate. For comparative purposes, $T$. naphthalenivorans CECT $7648^{\mathrm{T}}$ was tested in parallel as a reference.

Cell morphology, motility and flagella arrangement were observed on wet mounts under phase-contrast microscopy. Cells of strain $\mathrm{MD}^{\mathrm{T}}$ were small, straight, regular bacilli, $0.5-1 \mu \mathrm{m}$ wide and $2-2.5 \mu \mathrm{m}$ long, motile by polar flagella, as seen after flagella staining with the method of Heimbrook et al. (1989). In our laboratory, we were not able to see the peritrichous flagella reported by Harwati et al. (2009) in the description of T. naphthalenivorans. Cell size was determined by using electron microscopy at the Servicio Central de Soporte a la Investigación Experimental (University of Valencia). Samples were examined in a Hitachi S-4100 field emission scanning microscope with a 7-15 mm working distance and at an acceleration voltage of $10 \mathrm{kV}$. In addition, samples were examined using a transmission electron microscope (JEM-1010; JEOL) at $60 \mathrm{kV}$ after negative staining with $2 \%(\mathrm{w} / \mathrm{v})$ phosphotungstic acid at an appropriate $\mathrm{pH}$. A selection of images is given in Fig. S1, available in IJSEM Online.

The strain stained Gram-negative and cells lysed readily when suspended in $3 \%(\mathrm{w} / \mathrm{v}) \mathrm{KOH}$ solution. Cells grown for 5 days on MA or BMA plus citrate did not reveal polyhydroxybutyrate granules after staining with Nile blue A (Smibert \& Krieg, 1994).

Growth of $\mathrm{MD}^{\mathrm{T}}$ on $\mathrm{MA}\left(28^{\circ} \mathrm{C}, 48 \mathrm{~h}\right)$ yielded beige, brilliant and slightly umbonate colonies. Isolated colonies of strain $\mathrm{MD}^{\mathrm{T}}$ were about $1 \mathrm{~mm}$ in diameter with entire edges (MA, $28{ }^{\circ} \mathrm{C}, 48 \mathrm{~h}$ ). The ability to grow at different temperatures was tested on MA incubated at 4 and $15{ }^{\circ} \mathrm{C}$ (for 15 days) and $28,37,40$ and $45{ }^{\circ} \mathrm{C}$ (for $48 \mathrm{~h}$ ). The strain was able to grow at $15-37{ }^{\circ} \mathrm{C}$, but not at 4 or $40{ }^{\circ} \mathrm{C}$. Ion requirements were tested on salt tolerance agar (STA), containing $1 \%$ peptone, $0.3 \%$ yeast extract and $1.2 \%$ purified agar. This medium was supplemented with the following salt combinations (w/v): with (i) and without (ii) $2 \% \mathrm{NaCl}$, (iii) with $2 \% \mathrm{KCl}$, (iv) with $2 \% \mathrm{NaCl}$ and $0.9 \%$
$\mathrm{MgCl}_{2} \cdot 6 \mathrm{H}_{2} \mathrm{O}$, (v) with $2 \% \mathrm{NaCl}$ and $0.2 \% \mathrm{CaCl}_{2} \cdot 2 \mathrm{H}_{2} \mathrm{O}$, (vi) with $2 \% \mathrm{NaCl}$ and $0.06 \% \mathrm{KCl}$, (vii) with $2 \% \mathrm{NaCl}$, $0.9 \% \mathrm{MgCl}_{2} \cdot 6 \mathrm{H}_{2} \mathrm{O}$ and $0.2 \% \mathrm{CaCl}_{2} \cdot 2 \mathrm{H}_{2} \mathrm{O}$ and (viii) with $2 \% \mathrm{NaCl}, 0.9 \% \mathrm{MgCl}_{2} .6 \mathrm{H}_{2} \mathrm{O}, 0.2 \% \mathrm{CaCl}_{2} .2 \mathrm{H}_{2} \mathrm{O}$ and $0.06 \% \mathrm{KCl}$. Strain $\mathrm{MD}^{\mathrm{T}}$ required $\mathrm{Na}^{+}$plus a divalent cation (either $\mathrm{Mg}^{2+}$ or $\mathrm{Ca}^{2+}$ ) for growth, whereas $T$. naphthalenivorans CECT $7648^{\mathrm{T}}$ required specifically $\mathrm{Na}^{+}$ plus $\mathrm{Mg}^{2+}$ and did not show any growth with $\mathrm{Na}^{+}$plus $\mathrm{Ca}^{2+}$. Both strains were unable to grow with only $\mathrm{Na}^{+}$, only $\mathrm{K}^{+}$or with these two cations combined. The salinity range for growth was tested on MA as reported previously (Macián et al., 2005). Strain $\mathrm{MD}^{\mathrm{T}}$ showed good growth from 0.35 to $7 \%(\mathrm{w} / \mathrm{v})$ total salinity and no growth was observed at $8 \%$ salinity or higher. T. naphthalenivorans CECT $7648^{\mathrm{T}}$ showed the same minimum and maximum salinities for growth, in contrast with its original description, which reported its ability to grow with up to $15 \%$ salts.

Strain $\mathrm{MD}^{\mathrm{T}}$ was oxidase- and catalase-positive, unable to ferment glucose on $\mathrm{O} / \mathrm{F}$ medium and unable to reduce nitrate to nitrite (or gas) either in nitrate broth or API 20NE strips. In our laboratory, T. naphthalenivorans CECT $7648^{\mathrm{T}}$ was oxidase- and catalase-positive and unable to reduce nitrate to nitrite, in disagreement with the original description of the genus Tropicibacter (Harwati et al., 2009), defined as positive for nitrate reduction.

Results for strain $\mathrm{MD}^{\mathrm{T}}$ in API 20NE, API ZYM and Biolog GN2 kits are reported in the species description. Strain $\mathrm{MD}^{\mathrm{T}}$ and T. naphthalenivorans CECT $7648^{\mathrm{T}}$ were unable to oxidize any of the substrates contained in Biolog GN2 or gave weak responses. This is in sharp contrast with the description of T. naphthalenivorans (Harwati et al., 2009), where strain $\mathrm{C}_{2} 2^{\mathrm{T}}$ was reported as able to metabolize a large number of substrates in this system.

Fatty acid methyl esters were extracted and prepared at the CECT according to standard protocols described for the MIDI Microbial Identification System (Sasser, 1990). Cellular fatty acid content was analysed by GC with an Agilent 6850 chromatographic unit, with the MIDI Microbial Identification System using the RTSBA6 method (MIDI, 2008) and identified using the Microbial Identification Sherlock software package. Strain $\mathrm{MD}^{\mathrm{T}}, T$. naphthalenivorans CECT $7648^{\mathrm{T}}$, Phaeobacter inhibens CECT $7251^{\mathrm{T}}$, P. gallaeciensis CECT $7277^{\mathrm{T}}$, P. daeponensis CECT $7309^{\mathrm{T}}$, Shimia marina CECT $7688^{\mathrm{T}}$ and Nautella italica CECT $7645^{\mathrm{T}}$ were cultured on MA and incubated at $28{ }^{\circ} \mathrm{C}$ for $48 \mathrm{~h}$. The predominant fatty acid constituent of MD5 ${ }^{\mathrm{T}}$ and T. naphthalenivorans CECT $7648^{\mathrm{T}}$ was summed feature $8\left(\mathrm{C}_{18: 1} \omega 7 c\right.$ and/or $\left.\mathrm{C}_{18: 1} \omega 6 c\right)$. However, the fatty acid profile of strain $\mathrm{MD}^{\mathrm{T}}$ showed a distinctive pattern, allowing its differentiation from T. naphthalenivorans CECT $7648^{\mathrm{T}}$. Strain $\mathrm{MD}^{\mathrm{T}}$ possessed fatty acids $\mathrm{C}_{10: 0} 3-\mathrm{OH}, \mathrm{C}_{12: 0} 3-\mathrm{OH}$ and $\mathrm{C}_{16: 0} 2-\mathrm{OH}$ but not $\mathrm{C}_{12: 1} 3-\mathrm{OH}$ or $\mathrm{C}_{18: 1} \omega 9 c$ (Table 1 ).

Polar lipid analysis of strain $\mathrm{MD}^{\mathrm{T}}$ and T. naphthalenivorans CECT $7648^{\mathrm{T}}$ was performed at the CECT as follows. Polar lipids were extracted from $100 \mathrm{mg}$ freeze-dried cells and separated by two-dimensional silica-gel TLC (Tindall et al., 
Table 1. Cellular fatty acid compositions of strain $M D 5^{\top}$ and related type strains

Strains: 1, T. multivorans sp. nov. $\mathrm{MD}^{\mathrm{T}} ; 2$, T. naphthalenivorans CECT $7648^{\mathrm{T}} ; 3$, Phaeobacter inhibens CECT $7251^{\mathrm{T}} ; 4$, P. gallaeciensis CECT $7277^{\mathrm{T}}$; 5 , P. daeponensis CECT $7309^{\mathrm{T}}$; 6 , Shimia marina CECT $7688^{\mathrm{T}} ; 7$, Nautella italica CECT $7645^{\mathrm{T}}$. All data were obtained in this study (mean values of at least three replicates) using strains grown on MA for $48 \mathrm{~h}$ at $28{ }^{\circ} \mathrm{C}$. Cellular fatty acid analysis was carried out according to the Microbial Identification System (Microbial ID). Fatty acids that gave only trace amounts or were not detectable in all strains are not represented. - , Not detected; tr, trace amount $(<1 \%)$.

\begin{tabular}{|lcccccccc|}
\hline Fatty acid & $\mathbf{1}$ & $\mathbf{2}$ & $\mathbf{3}$ & $\mathbf{4}$ & $\mathbf{5}$ & $\mathbf{6}$ & $\mathbf{7}$ \\
\hline Hydroxy & & & & & & & \\
$\mathrm{C}_{10: 0} 3-\mathrm{OH}$ & 4.8 & - & 2.4 & 2.6 & 2.5 & 9.5 & 2.9 \\
$\mathrm{C}_{12: 0} 3-\mathrm{OH}$ & 1.0 & - & 1.8 & 2.4 & 2.4 & 2.4 & 2.4 \\
$\mathrm{C}_{12: 1} 3-\mathrm{OH}$ & - & 3.4 & - & - & - & - & - \\
$\mathrm{C}_{16: 0} 2-\mathrm{OH}$ & 3.8 & - & 1.7 & 3.4 & 3.1 & - & 1.2 \\
$\mathrm{C}_{18: 0} 3-\mathrm{OH}$ & - & - & - & - & - & 1.1 & - \\
Saturated & & & & & & & \\
$\mathrm{C}_{9: 0}$ & $\operatorname{tr}$ & 1.5 & - & $\operatorname{tr}$ & - & - & - \\
$\mathrm{C}_{12: 0}$ & $\operatorname{tr}$ & $\operatorname{tr}$ & $\operatorname{tr}$ & $\operatorname{tr}$ & 0.9 & 1.0 & $\operatorname{tr}$ \\
$\mathrm{C}_{14: 0}$ & 0.9 & 2.1 & $\operatorname{tr}$ & 0.9 & $\operatorname{tr}$ & $\operatorname{tr}$ & $\operatorname{tr}$ \\
$\mathrm{C}_{16: 0}$ & 8.2 & 7.4 & 7.2 & 9.0 & 2.3 & 6.2 & 4.0 \\
$\mathrm{C}_{18: 0}$ & 2.7 & 6.9 & 1.7 & 3.3 & 1.0 & 1.9 & 1.2 \\
iso-C $18: 0$ & - & - & - & $\operatorname{tr}$ & 3.8 & - & 4.7 \\
Unsaturated & & & & & & & \\
$11-$ Methyl & 5.3 & 1.8 & 8.6 & 8.1 & 9.7 & 2.2 & 1.3 \\
$\mathrm{C}_{18: 1} \omega 7 c$ & & & & & & & \\
$\mathrm{C}_{18: 1} \omega 9 c$ & - & 1.3 & - & - & - & - & - \\
Summed feature & $8 *$ & 70.9 & 73.5 & 73.7 & 68.0 & 71.6 & 69.5 & 81.0 \\
\hline
\end{tabular}

* Summed features are groups of two or three fatty acids that cannot be separated by GLC with the MIDI System. Summed feature 8 contained $\mathrm{C}_{18: 1} \omega 7 c$ and/or $\mathrm{C}_{18: 1} \omega 6 c$.

2007). Total lipid material was stained with molybdatophosphoric acid followed by heating at $150{ }^{\circ} \mathrm{C}$ for $15 \mathrm{~min}$. For the visualization of specific functional groups, $\alpha$-naphthol/ sulphuric acid, ninhydrin, molybdenum blue and Dragendorff's reagent were used, as described previously (Tindall et al., 2007). The two strains showed very similar profiles, and the major identifiable components were phosphatidylethanolamine, phosphatidylglycerol and phosphatidylcholine (Fig. S2).

Analysis of respiratory quinones was carried out by the Identification Service of the DSMZ and Dr B. J. Tindall (DSMZ). Strain $\mathrm{MD}^{\mathrm{T}}$ had a ubiquinone system (Q-10) that was in agreement with reported data for other members of the Roseobacter clade.

Sample preparation for matrix-assisted laser-desorption/ ionization time-of-flight mass spectrometry (MALDI-TOF MS) protein analysis was carried out at the CECT according to the ethanol/formic acid extraction protocol recommended by Bruker Daltonics (http://www.bdal.de). MALDI-TOF MS was conducted using a Reflex IV mass spectrometer (Bruker Daltonics) equipped with a $\mathrm{N}_{2}$ laser. All spectra were recorded in linear positive-ion mode. The acceleration voltage was $20 \mathrm{kV}$. Spectra were collected as a sum of 240 shots across a spot, and 12-16 spots per strain. A mass range of 2000-20000 Da was used for analysis. Peak recognition and comparison of the spectra were done with the BioTyper software 1.1 as described by Maier et al. (2006). The dendrogram obtained with MALDI-TOF MS illustrates that strain $\mathrm{MD}^{\mathrm{T}}$ and T. naphthalenivorans CECT $7648^{\mathrm{T}}$ can be separated clearly from each other and from members of the related genera Phaeobacter, Nautella and Shimia (Fig. S3).

The DNA $\mathrm{G}+\mathrm{C}$ content was determined by the Identification Service of the DSMZ by HPLC according to the method described by Tamaoka \& Komagata (1984) and Mesbah et al. (1989) as $60.7 \mathrm{~mol} \%$.

The almost-complete 16S rRNA gene sequence of strain $M D 5^{\mathrm{T}}$ was obtained in this study. A cell pellet was collected and DNA was extracted using a microbial DNA isolation kit (Ultra Clean; Mo Bio Laboratories). Amplification and partial sequencing of the $16 \mathrm{~S}$ rRNA gene was performed as described previously (Lucena et al., 2010). In parallel, a stretch of around $1000 \mathrm{nt}$ close to the $5^{\prime}$ end of the $16 \mathrm{~S}$ rRNA gene was sequenced for strain T. naphthalenivorans CECT $7648^{\mathrm{T}}$ as an authenticity control, following the protocol described by Arahal et al. (2008). In both cases, PCR amplicons of MD5 ${ }^{\mathrm{T}}$ and T. naphthalenivorans CECT $7648^{\mathrm{T}}$ were purified using the UltraClean PCR clean-up kit. Subsequent sequencing reactions were done on an ABI Prism 3730 automated sequencer using the Big Dye Terminator version 3.1 cycle sequencing kit, premixed format. Sequencing primers were the same as those used in the amplification reaction but diluted tenfold (5 pmol). The newly obtained sequences were compared with publicly available sequences in the GenBank/EMBL/DDBJ databases using the BLAST program (National Center for Biotechnology Information; http://ncbi.nlm.nih.gov/). Related sequences were further analysed using the ARB program package (Ludwig et al., 2004; http://www.arb-home.de). Automated sequence alignments were corrected manually using the ARB_EDIT sequence editor. Alignments retrieved from the latest updates of SILVA and LTP (Pruesse et al., 2007; Yarza et al., 2010) were also used as references. Phylogenetic analysis using alternative treeing methods (maximum-parsimony, maximum-likelihood and distance matrix) and data subsets were performed using the appropriate ARB tools (Ludwig et al., 2004). Phylogenetic analysis of the 16 S rRNA gene confirmed that strain $\mathrm{MD}^{\mathrm{T}}$ belongs to the genus Tropicibacter, branching always together with $T$. naphthalenivorans.

$16 \mathrm{~S}$ rRNA gene sequence analysis showed that sequence AB302370, corresponding to the type strain T. naphthalenivorans $\mathrm{C}_{2} 2^{\mathrm{T}}$, showed the highest similarity $(96.9 \%)$ to the sequence of strain $\mathrm{MD5}^{\mathrm{T}}$, whereas $P$. inhibens $\mathrm{T}^{\mathrm{T}}$ exhibited

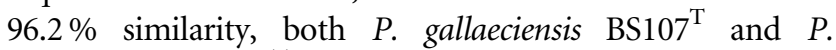
daeponensis TF- $218^{\mathrm{T}}$ showed $96.1 \%$ similarity and the type strains of other species with validly published names showed less than $95.9 \%$ similarity to the sequence of strain $\mathrm{MD}^{\mathrm{T}}$. 
In the phylogenetic tree based on the maximum-parsimony algorithm (Fig. 1), strain $\mathrm{MD}^{\mathrm{T}}$ formed a robust clade with T. naphthalenivorans $\mathrm{C} 02^{\mathrm{T}}$ (with a bootstrap resampling value of $100 \%$ ). The same local topology was obtained in phylogenetic trees generated by the neighbour-joining and maximum-likelihood algorithms (Figs S4 and S5). Although species of Phaeobacter show the highest sequence similarity to strain $\mathrm{MD}^{\mathrm{T}}$ and $T$. naphthalenivorans, they formed separate branches in all phylogenetic trees (neighbourjoining, maximum-parsimony and maximum-likelihood).

Our phenotypic results, including chemotaxonomic properties, and phylogenetic results (tree topology and sequence similarities of the 16S rRNA gene) allow us to conclude that strain $\mathrm{MD}^{\mathrm{T}}$ represents a novel species of the genus Tropicibacter. Thus, we propose Tropicibacter multivorans sp. nov., with strain $\mathrm{MD5}^{\mathrm{T}}$ as the type strain. The novel species can be readily differentiated from $T$. naphthalenivorans by phenotypic traits, as shown in Tables 2 and S1.

\section{Description of Tropicibacter multivorans sp. nov.}

Tropicibacter multivorans (mul'ti.vor'ans. L. adj. multus many, numerous; L. v. vorare to devour, swallow; N.L. part. adj. multivorans devouring many, referring to the utilization of numerous different substrates for growth).

Cells are Gram-negative, motile by means of polar flagella and rod-shaped $(2-2.5 \mu \mathrm{m}$ long and $0.5-1 \mu \mathrm{m}$ wide). Aerobic and chemo-organotrophic. Oxidase- and catalasepositive. Does not produce acid in O/F medium (with MCS) from D-glucose under either aerobic or anaerobic conditions. Cells do not contain polyhydroxybutyrate. Grows on MA, producing regular colonies ( $1 \mathrm{~mm}$ diameter) after $24 \mathrm{~h}$ at $28{ }^{\circ} \mathrm{C}$. Grows at $15-37{ }^{\circ} \mathrm{C}$ but not at 4 or $40{ }^{\circ} \mathrm{C}$. Does not ferment carbohydrates and is negative for nitrate reduction. Requires the addition of $\mathrm{Na}^{+}$and divalent cations $\mathrm{Mg}^{2+}$ or $\mathrm{Ca}^{2+}$ ) for growth. Good growth on 1.7-7\% total salts, but no growth is observed at $0.35 \%$ or less or at $8 \%$ salinity or more. Hydrolysis of gelatin, casein, starch, alginate, agar and
Tween 80 is negative after 1 week. DNA is hydrolysed in DNase agar medium supplemented with MCS, although the halo of hydrolysis is small. In API 20NE strips, positive for hydrolysis of urea and aesculin, $\beta$-galactosidase (PNPG test) and assimilation of $\mathrm{D}$-glucose, maltose, adipate and malate and negative for nitrate reduction, indole production from tryptophan, D-glucose fermentation, arginine dihydrolase, gelatin hydrolysis and assimilation of L-arabinose, Dmannose, $\mathrm{N}$-acetylglucosamine, gluconate and caprate. Assimilation of D-mannitol, citrate and phenylacetate is variable. Enzyme activities displayed in API ZYM are alkaline and acid phosphatases, leucine arylamidase and $\alpha$ glucosidase. Tests for the remaining activities are negative. Carbon sources that sustain abundant growth on BMA are D-ribose, D-xylose, D-glucose, D-fructose, D-galactose, Dmannose, cellobiose, glycerol, D-mannitol, D-sorbitol, myoinositol, acetate, pyruvate, propionate, butyrate, citrate, 2-oxoglutarate, succinate, fumarate, malate, lactate, 3hydroxybutyrate, L-leucine, D-serine, L-threonine, L-glutamate, L-alanine, L-arginine, L-tyrosine, L-ornithine, L-aspartate and L-histidine. The following organic acids, amino acids and carbohydrates are not used: L-arabinose, trehalose, Lrhamnose, maltose, sucrose, lactose, melibiose, amygdalin, salicin, $N$-acetyl-D-glucosamine, D-gluconate, D-glucuronate, D-galacturonate, D-glycerate, D-saccharate, trans-aconitate, glycine, L-citrulline, 4-aminobutyrate, L-lysine, $\mathrm{L}$-sarcosine and putrescine. Oxidation of substrates on Biolog GN2 microplates after $48 \mathrm{~h}$ of incubation is negative or borderline for all substrates. The most abundant cellular fatty acids are summed feature $8 \quad\left(\mathrm{C}_{18: 1} \omega 7 c\right.$ and/or $\left.\mathrm{C}_{18: 1} \omega 6 c\right), \mathrm{C}_{16: 0}, 11$-methyl $\mathrm{C}_{18: 1} \omega 7 c$ and $\mathrm{C}_{10: 0} 3-\mathrm{OH}$. Detected polar lipids include phosphatidylethanolamine, phosphatidylglycerol, phosphatidylcholine, an aminolipid and four unidentified phospholipids. Its respiratory quinone is $\mathrm{Q}-10$. The DNA $\mathrm{G}+\mathrm{C}$ content of the type strains is $60.7 \mathrm{~mol} \%$ (HPLC).

The type strain, MD5 $^{\mathrm{T}}\left(=\mathrm{CECT} 7557^{\mathrm{T}}=\mathrm{KCTC} 23350^{\mathrm{T}}\right)$, was isolated from coastal seawater at Valencia (Spain).

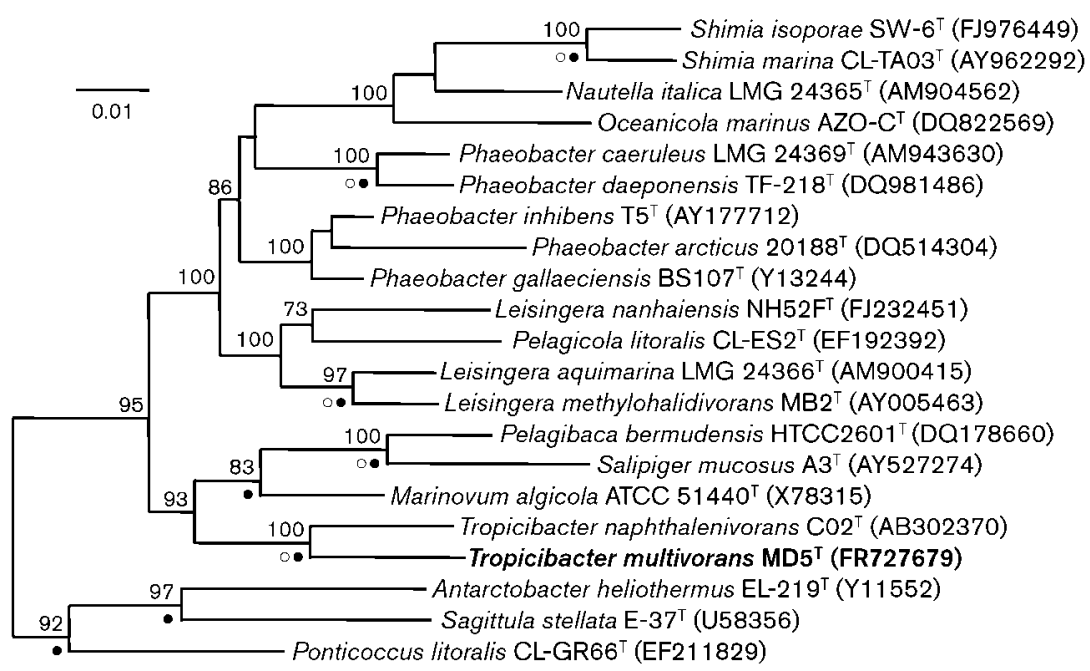

Fig. 1. Maximum-parsimony phylogenetic tree based on almost-complete 16S rRNA gene sequences of strain $\mathrm{MD5}^{\top}$ (Tropicibacter multivorans sp. nov.) and closely related strains. Accession numbers are given in parentheses. Bootstrap values greater than $70 \%$ are shown at branching points (percentages of 1000 resamplings). Nodes coincident in the maximum-likelihood and neighbour-joining trees are respectively indicated by open and closed circles. Bar, 0.01 substitutions per nucleotide position. 
Table 2. Differential characteristics between T. multivorans sp. nov. $\mathrm{MD5}^{\top}$ and T. naphthalenivorans CECT $7648^{\top}$

Strains: 1, T. multivorans sp. nov. $\mathrm{MD}^{\mathrm{T}} ; 2$, T. naphthalenivorans CECT $7648^{\mathrm{T}}$. All data were obtained in this study. +, Positive; -, negative or not detected.

\begin{tabular}{|lcc|}
\hline Characteristic & $\mathbf{1}$ & $\mathbf{2}$ \\
\hline Growth at $40{ }^{\circ} \mathrm{C}$ & - & + \\
Specific requirement for $\mathrm{Mg}^{2+}$ & - & + \\
Assimilation of (API 20NE): & & \\
$\quad$ D-Glucose & + & - \\
$\quad$ Maltose & + & - \\
Adipate & + & - \\
Malate & + & - \\
Enzyme activities (API ZYM) & & \\
$\quad \alpha$-Glucosidase & + & - \\
$\beta$-Glucosidase & - & + \\
Use of sole carbon sources on BMA & & \\
D-Ribose, D-xylose, D-mannose, & + & - \\
$\quad$ cellobiose, D-mannitol, D-sorbitol, & & \\
myo-inositol & & \\
Acetate, pyruvate, propionate, & + & - \\
$\quad$ butyrate, malate, 3-hydroxybutyrate & & \\
L-Leucine, L-threonine, L-glutamate, & + & - \\
L-alanine, L-arginine, L-ornithine, & & \\
L-aspartate, L-histidine & & \\
Presence of cellular fatty acids & & \\
$\mathrm{C}_{10: 0}$ 3-OH & \\
$\mathrm{C}_{12: 1}$ 3-OH & & \\
$\mathrm{C}_{16: 0}$ 2-OH & & - \\
& & \\
\end{tabular}

\section{Acknowledgements}

Thanks are due to María José Ros and Adrián Vila for their excellent technical assistance. This work was supported by the Spanish Ministerio de Educación y Ciencia (projects CGL2005-02292 and CGL2010-18134 to M. J. P.).

\section{References}

Arahal, D. R., Sánchez, E., Macián, M. C. \& Garay, E. (2008). Value of recN sequences for species identification and as a phylogenetic marker within the family "Leuconostocaceae". Int Microbiol 11, 33-39.

Baumann, P. \& Baumann, L. (1981). The marine gram-negative eubacteria: genera Photobacterium, Beneckea, Alteromonas, Pseudomonas and Alcaligenes. In The Prokaryotes, vol. 2, pp. 1302-1331. Edited by M. P. Starr, H. Stolp, H. G. Trüper, A. Balows \& H. Schleger. Berlin \& Heidelberg: Springer.

Farmer, J. J., III \& Hickman-Brenner, F. W. (2006). The genera Vibrio and Photobacterium. In The Prokaryotes, 3rd edn, pp. 508-563. Edited by M. Dworkin, S. Falkow, E. Rosenberg, K. H. Schleifer \& E. Stackebrandt. New York: Springer.
Harwati, T. U., Kasai, Y., Kodama, Y., Susilaningsih, D. \& Watanabe, K. (2009). Tropicibacter naphthalenivorans gen. nov., sp. nov., a polycyclic aromatic hydrocarbon-degrading bacterium isolated from Semarang Port in Indonesia. Int J Syst Evol Microbiol 59, 392-396.

Heimbrook, M. E., Wang, W. L. L. \& Campbell, G. (1989). Staining bacterial flagella easily. J Clin Microbiol 27, 2612-2615.

Lucena, T., Pascual, J., Garay, E., Arahal, D. R., Macián, M. C. \& Pujalte, M. J. (2010). Haliea mediterranea sp. nov., a marine gammaproteobacterium. Int J Syst Evol Microbiol 60, 1844-1848.

Ludwig, W., Strunk, O., Westram, R., Richter, L., Meier, H., Yadhukumar, Buchner, A., Lai, T., Steppi, S. \& other authors (2004). ARB: a software environment for sequence data. Nucleic Acids Res 32, 1363-1371.

Macián, M. C., Ludwig, W., Aznar, R., Grimont, P. A. D., Schleifer, K. H., Garay, E. \& Pujalte, M. J. (2001). Vibrio lentus sp. nov., isolated from Mediterranean oysters. Int J Syst Evol Microbiol 51, 1449-1456.

Macián, M. C., Arahal, D. R., Garay, E., Ludwig, W., Schleifer, K.-H. \& Pujalte, M. J. (2005). Thalassobacter stenotrophicus gen. nov., sp. nov., a novel marine $\alpha$-proteobacterium isolated from Mediterranean sea water. Int J Syst Evol Microbiol 55, 105-110.

Maier, T., Klepel, S., Renner, U. \& Kostrzewa, M. (2006). Fast and reliable MALDI-TOF MS-based microorganism identification. Nat Methods 3, i-ii.

Mesbah, M., Premachandran, U. \& Whitman, W. B. (1989). Precise measurement of the $\mathrm{G}+\mathrm{C}$ content of deoxyribonucleic acid by highperformance liquid chromatography. Int J Syst Bacteriol 39, 159-167.

MIDI (2008). Sherlock Microbial Identification System Operating Manual, version 6.1. Newark, DE: MIDI Inc.

Pruesse, E., Quast, C., Knittel, K., Fuchs, B. M., Ludwig, W., Peplies, J. \& Glöckner, F. O. (2007). SILVA: a comprehensive online resource for quality checked and aligned ribosomal RNA sequence data compatible with ARB. Nucleic Acids Res 35, 7188-7196.

Sasser, M. (1990). Identification of bacteria by gas chromatography of cellular fatty acids, MIDI Technical Note 101. Newark, DE: MIDI Inc.

Shiba, T. (1991). Roseobacter litoralis gen. nov., sp. nov., and Roseobacter denitrificans sp. nov., aerobic pink-pigmented bacteria which contain bacteriochlorophyll a. Syst Appl Microbiol 14, 140-145.

Smibert, R. M. \& Krieg, N. R. (1994). Phenotypic characterization. In Methods for General and Molecular Bacteriology, pp. 607-654. Edited by P. Gerhardt, R. G. E. Murray, W. A. Wood \& N. R. Krieg. Washington, DC: American Society for Microbiology.

Tamaoka, J. \& Komagata, K. (1984). Determination of DNA base composition by reversed-phase high-performance liquid chromatography. FEMS Microbiol Lett 25, 125-128.

Tindall, B. J., Sikorski, J., Smibert, R. M. \& Krieg, N. R. (2007). Phenotypic characterization and the principles of comparative systematics. In Methods for General and Molecular Microbiology, pp. 330-393. Edited by C. A. Reddy, T. J. Beveridge, J. A. Breznak, G. Marzluf, T. M. Schmidt \& L. R. Snyder. Washington, DC: American Society for Microbiology.

Yarza, P., Ludwig, W., Euzéby, J., Amann, R., Schleifer, K. H., Glöckner, F. O. \& Rosselló-Móra, R. (2010). Update of the All-Species Living Tree Project based on $16 \mathrm{~S}$ and $23 \mathrm{~S}$ rRNA sequence analyses. Syst Appl Microbiol 33, 291-299. 